\title{
The effect of recycled coarse aggregate (RCA) with surface treatment on concrete mechanical properties
}

\author{
Anggun Tri Atmajayanti ${ }^{1, *}$, Chrisyanto Daniel Saragih G. ${ }^{1}$, and Yanuar Haryanto ${ }^{2}$ \\ ${ }^{1}$ Atma Jaya Yogyakarta University, Department of Civil Engineering, J1. Babarsari No. 44, Yogyakarta, \\ 55281, Indonesia \\ ${ }^{2}$ Jenderal Soedirman University, Civil Engineering Department, Jl. Mayjend.Sungkono KM 5, Blater, \\ Purbalingga, 53371, Indonesia
}

\begin{abstract}
This paper discusses the recycling system for concrete needed due to environmental and resource preservation issues. Construction and demolition waste is one problem faced in the construction site. One feasible solution to overcome this problem is by utilizing construction and demolition waste as a recycled coarse aggregate (RCA). This study aims to observe concrete mechanical properties using RCA with surface treatment. Acrylic-based material is used to treat the surface of recycled coarse aggregate (RCA) by spraying it from two sides. It is found that the recycled aggregate with surface treatment may reduce water absorption from $7.96 \%$ to $2.96 \%$. In addition, the concrete using RCA with surface treatment may improve the compressive strength, modulus of elasticity and split tensile strength.
\end{abstract}

\section{Introduction}

Sustainable development which is environmentally friendly and focuses mainly on environmental preservation has become a necessity in the construction field, including the utilization of construction and demolition waste. Construction and demolition waste is defined as solid waste generated from the construction, renovation, changing, or demolition processes of houses, institutional or government buildings, industrial buildings, and commercial facilities as well as other infrastructure such as roads, bridges, dams, tunnels, railways, and airports [1], some of which may be utilized as recycled coarse aggregate (RCA) [2]. RCA may also result from recycled concrete waste processes. RCA has been used as a low added-value utilization for applications including land reclamation, filling, sub-base road material, and concrete secondary products manufacturing [3]. However, with the advanced development of technology, recent waste management may result in recycled aggregate with

\footnotetext{
* Corresponding author: anggun.atmajayanti@uajy.ac.id
} 
quality equal to the natural aggregate (NA). Thus, the potential of RCA as a structural element and for high added-value utilization has been rapidly growing [4].

The concrete made using recycled aggregate is called recycled aggregate concrete. There are some key factors and characteristics of recycled aggregate concrete compared to normal concrete. The recycled aggregate normally has a higher water absorption value and lower specific gravity than that of the normal aggregate [5]. The porosity of recycled aggregate is also much higher than that of natural aggregate [6]. RCA derived from recycled concrete waste has a higher water absorption value than NA since there are remaining mortar layers attached to the recycled aggregate which enable it to hold more water in its pores [7]. Shayan and $\mathrm{Xu}$ [8] found water absorption values of $0.5-1 \%$ for NA and $4-4.7 \%$ for RCA in the saturated surface dry condition, up to a difference of $4.2 \%$. Other studies have shown similar differences in which RCA absorption was 5.6 and 4.9-5.2\% compared to NA absorption of 1.0 and $2.5 \%[9,10]$.

This study aims at observing the mechanical properties of concrete utilizing RCA with surface treatment (ST). Tsujino et al. [11] argue that surface treatment on low and medium quality recycled aggregate may reduce water absorption. Some studies related to surface treatment on RCA have been previously conducted. Junak and Sicakova [12] have modified the surface properties of RCA using a geo-polymer material based on fly ash and conclude that RCA surface modification results in increased density and compressive strength and reduced total water absorption. It is observed that RCA pores were filled with the geopolymer slurry, making it difficult for water to penetrate the pores and consequently reducing the absorption rate. The study conducted by Spaeth and Tegguer [13] on the improvement of RCA properties with polymer treatments demonstrated a significant decrease in RCA water absorption. In addition, the polymer treatments appear to be appropriate on RCA. The experimental results conducted by Kukadia et al. [14] using three types of treatment under consideration for recycled aggregate: abrasion, cement slurry coating, and chemical immersion. The results show that recycled aggregate concrete compressive strength may be significantly improved, and the strength may reach up to $39.73 \mathrm{MPa}$ which is considered sufficient for structural applications.

\section{Experimental work}

The materials used for the concrete mixtures include Portland Pozzolan Cement (PPC), a fine aggregate of sand taken from the Progo River, Yogyakarta, as well as a natural coarse aggregate taken from Clereng, Kulon Progro, Yogyakarta. The RCA (Figure 1) in the form of concrete waste was generated by the Building Structure and Material Laboratory of Atma Jaya University, Yogyakarta. The fine aggregate had a specific gravity of 2.63 with a fine modulus of 3.54. The natural course aggregate had a specific gravity of 2.57 with a fine modulus of 6.49 . The RCA without surface treatment had a specific gravity of 2.34 with a water absorption value of $7.96 \%$. Surface treatment was conducted on the recycled aggregate using acrylic material-based waterproofing with the trade brand Sikagard 800G (Figure 2), which is a polymer type regularly used for coating exposed concrete or natural stones. The surface treatment resulted in the RCA possessing a specific gravity of 2.31 and water absorption value of $2.97 \%$.

The RCA used are classified as low quality. BSTx code is utilized to facilitate the use of surface treated RCA in concrete, while BnSTx is a concrete using RCA without surface 
treatment. Code $\mathrm{x}$ shows the quantity of RCA utilized as a natural aggregate substitute. This study used RCA proportions of $50 \%$ and $100 \%$ within the concrete mixture. The composition of materials needed per $\mathrm{m}^{3}$ concrete mixture are presented in Table 1.

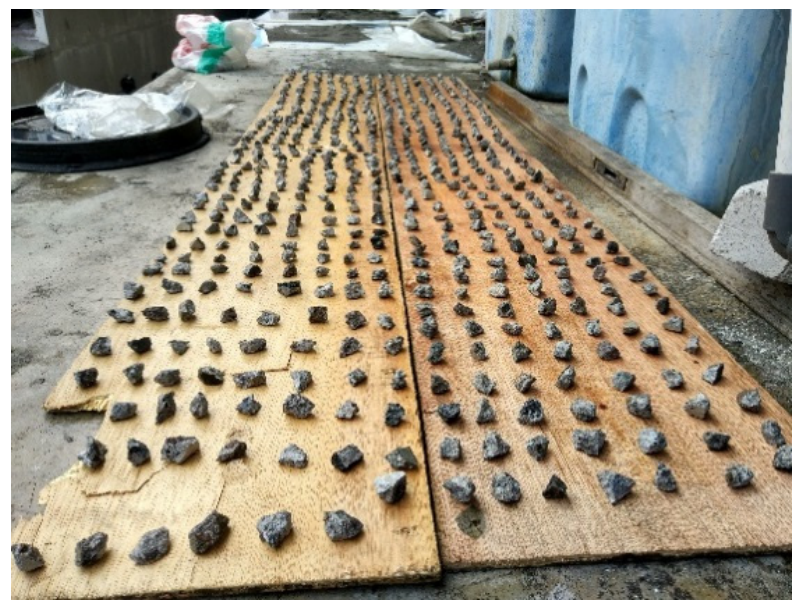

Fig. 1. Recycled coarse aggregate (RCA).

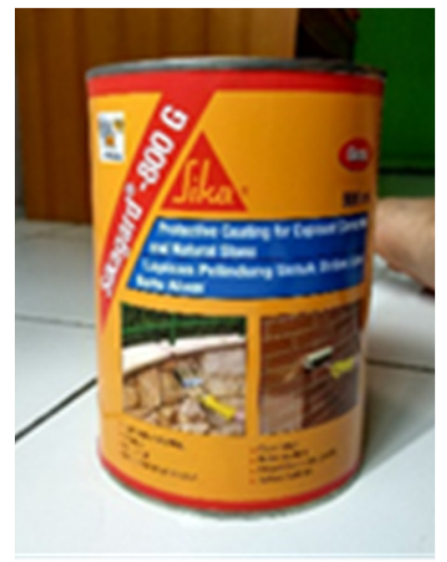

Fig. 2. Surface treatment materials.

Table 1. Concrete mixture compositions.

\begin{tabular}{|l|c|c|c|c|}
\hline Specimens & BST50 & BST100 & BnST50 & BnST100 \\
\hline PPC (kg) & 465.68 & 465.68 & 465.68 & 465.68 \\
\hline Fine Aggregate (kg) & 644.28 & 644.28 & 649.61 & 649.61 \\
\hline Natural Coarse Aggregate (kg) & 493.66 & 0 & 493.66 & 0 \\
\hline ST Recycled Aggregate (kg) & 444.29 & 927.14 & 0 & 0 \\
\hline Non-ST Recycled Aggregate (kg) & 0 & 0 & 450.41 & 934.81 \\
\hline Water (liter) & 204.9 & 204.9 & 204.9 & 204.9 \\
\hline
\end{tabular}

To verify the workability of the concrete mixtures, a slump test was conducted based on SNI 1972: 2008 [15]. A compressive strength test (Figure 3) and a split cylinder strength test (Figure 4) were conducted on day 28 on 24 cylindrical test specimens with a height of 300 
mm and a diameter of $150 \mathrm{~mm}$, based on SNI 1974: 2011 and SNI 03-2491-2002 [16, 17]. A modulus of elasticity test was conducted in accordance with SNI 03-4169-1996 [18]. The concrete compressive strength was determined using Equation 1. The split tensile strength was determined using Equation 2. The modulus of elasticity was determined using Equation 3.

$$
\begin{gathered}
f_{c}^{\prime}=\frac{P}{A} \\
f_{c t}=\frac{2 P}{\pi L d} \\
E=\frac{S_{2}-S_{1}}{\varepsilon_{s}-0.00005}
\end{gathered}
$$

where:
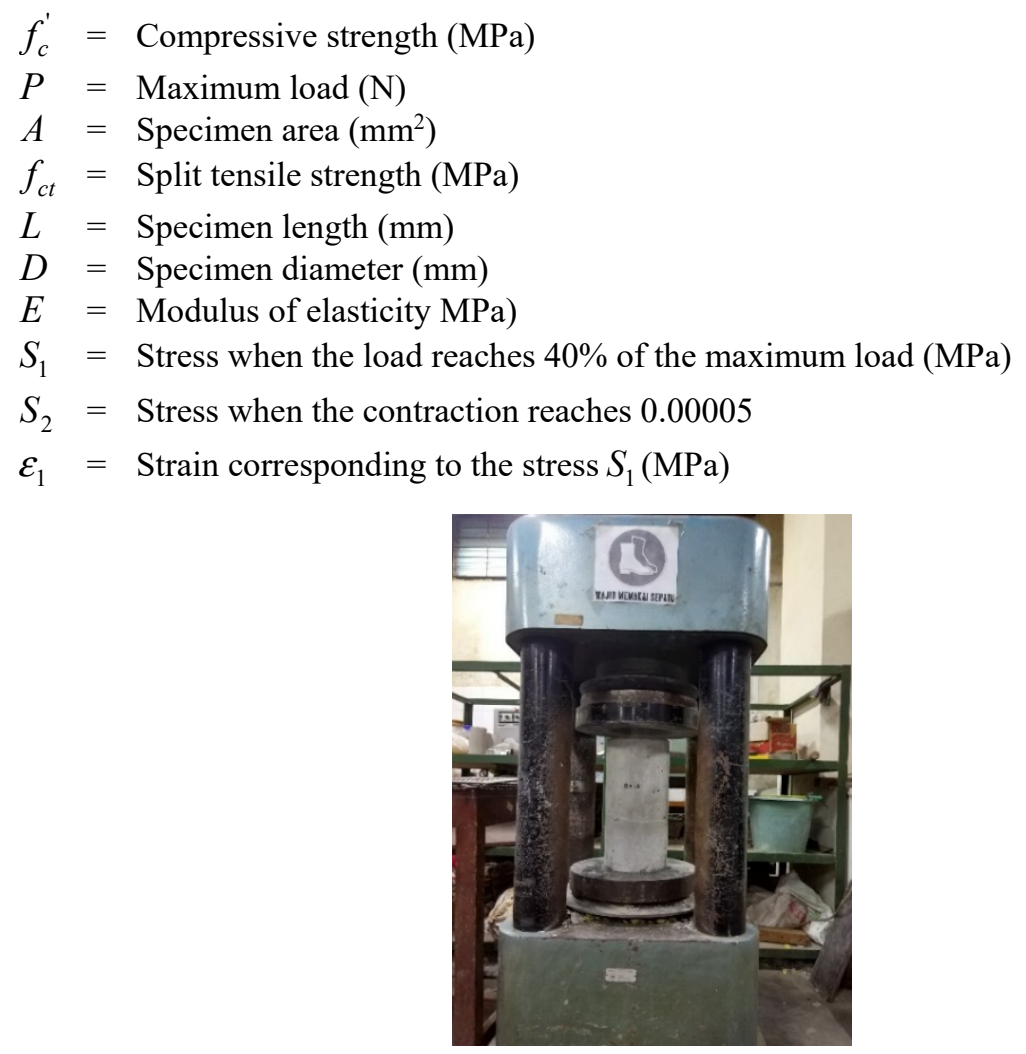

Fig. 3. Compressive strength test. 


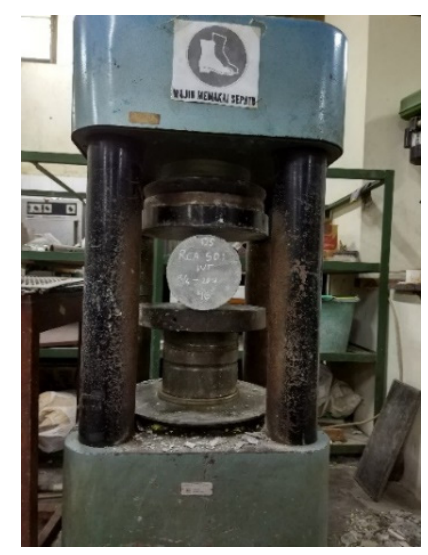

Fig. 4. Split tensile strength test.

\section{Results and discussion}

\subsection{Workability}

During concrete blending and mixture, some adjustments especially with the utilization of water were performed that influence the value of the $\mathrm{W} / \mathrm{C}$ ratio, resulting in a corrected value of the $\mathrm{W} / \mathrm{C}$ ratio. Table 2 shows that all compositions of the concrete mixture in this study have met the workability standards.

Table 2. Slump value.

\begin{tabular}{|c|c|c|}
\hline Specimens & Slump Value (mm) & W/C Ratio \\
\hline BnST50 & 85 & 0.44 \\
\hline BST50 & 80 & 0.41 \\
\hline BnST100 & 85 & 0.45 \\
\hline BST100 & 80 & 0.42 \\
\hline
\end{tabular}

\subsection{Density}

The surface treatment performed on the recycled coarse aggregate does not influence the concrete density. Based on SNI 03-2844-2000 [19], the recycle aggregate concrete generated from this study was categorized as normal concrete since the average density of each specimen is between $2200-2500 \mathrm{~kg} / \mathrm{m}^{3}$ as shown in Table 3 .

Table 3. Concrete density.

\begin{tabular}{|c|c|c|}
\hline Specimens & Density $\mathbf{( k g / \mathbf { m } ^ { 3 } )}$ & Category \\
\hline BnST50 & 2404.06 & normal concrete \\
\hline BST50 & 2423.61 & normal concrete \\
\hline BnST100 & 2393.29 & normal concrete \\
\hline BST100 & 2353.64 & normal concrete \\
\hline
\end{tabular}




\subsection{Mechanical properties}

The substitution percentage increase of RCA from $50 \%$ to $100 \%$ may decrease the compressive strength by $2.84 \%$. To generate recycled aggregate concrete with similar consistency to normal concrete, water addition is quite necessary due to the high-water absorption of RCA. The water addition is intended to lower the compressive strength. The surface treatment performed on the RCA may lower the water absorption level, decreasing the quantity of water needed to eventually improve the compressive strength by $2.46 \%$ and $2.38 \%$ respectively for the RCA $50 \%$ and $100 \%$. For similar reasons, the split tensile strength decreased by $5.83 \%$ and the modulus elasticity by $5.08 \%$ by increasing the substitution of RCA from $50 \%$ to $100 \%$. Furthermore, the surface treatment performed on the RCA may improve the split tensile strength by $2.59 \%$ and $8.25 \%$, as well as the modulus of elasticity by $13.14 \%$ and $0.69 \%$, respectively for RCA $50 \%$ and $100 \%$. The testing result of the average mechanical properties may be completely seen in Figure 5.

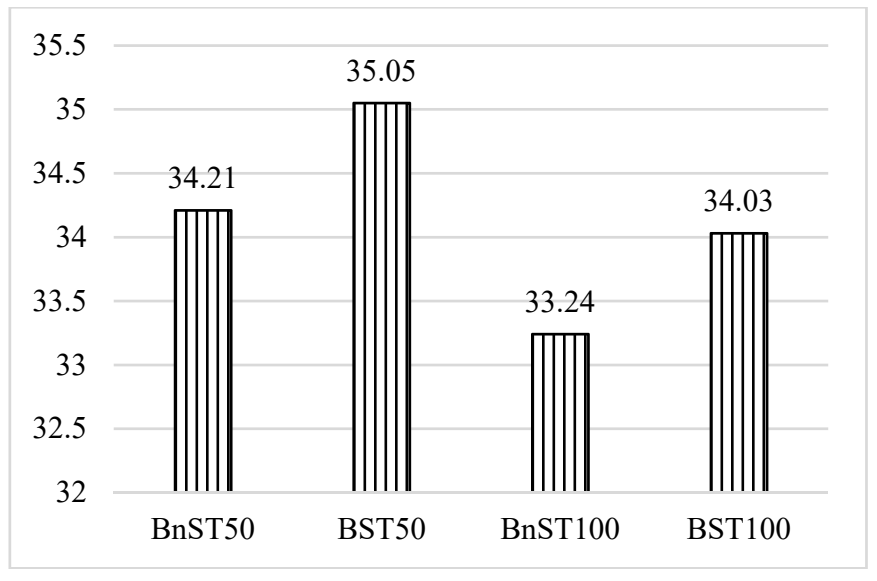

(a) Compressive strength

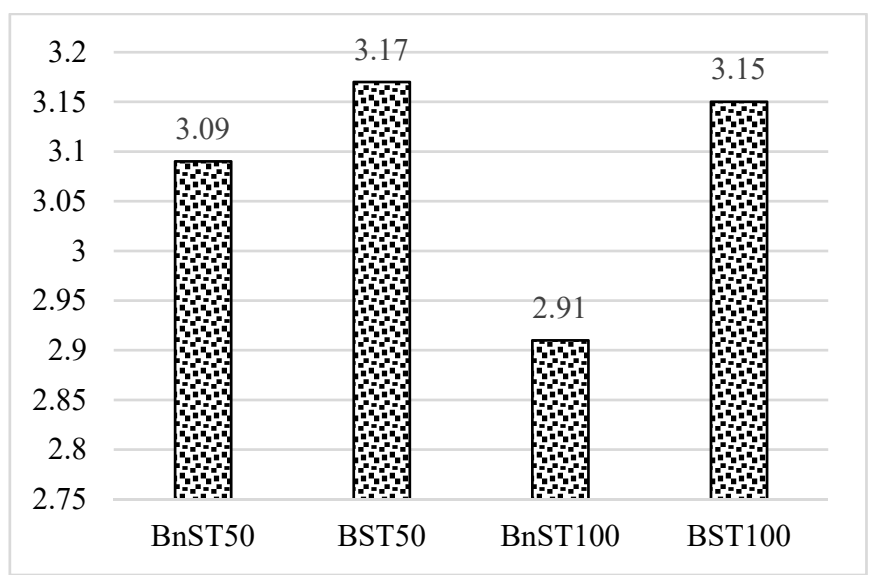

(b) Split tensile strength 


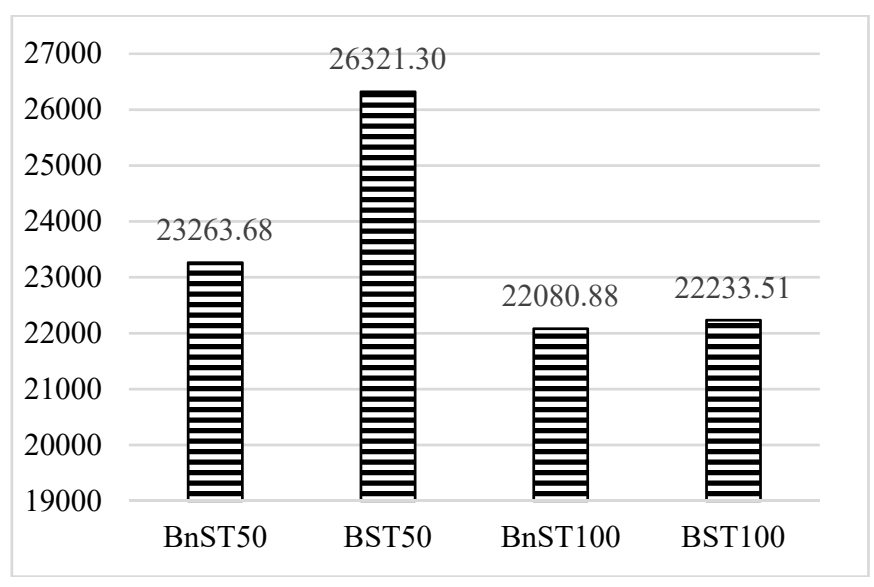

(c) Modulus of elasticity

Fig. 5. Mechanical properties.

\section{Conclusions}

All concrete mixture compositions available in this study have met the workability standards based on a slump test. The recycled aggregate concrete used in this study was categorized as normal concrete as the average density was $2200-2500 \mathrm{~kg} / \mathrm{m}^{3}$. The surface treatment on the RCA may have reduced the water absorption from $7.96 \%$ to $2.96 \%$. Compressive strength increases of $2.46 \%$ and $2.38 \%$, spit tensile strength increases of $2.59 \%$ and $8.25 \%$, as well as modulus of elasticity increases of $13.14 \%$ and $0.69 \%$ were observed, respectively for substitutions of RCA by $50 \%$ and $100 \%$.

\section{References}

1. S. Saha, C. Rajasekaran, Adv. Concr. Const. 4, 27 (2016)

2. S. Shahidan, M.A.M Azmi, S.S.M Zuki, K. Kupusamy, N. Ali, Pro. Eng. 174, 1028 (2017)

3. Y. Kim, J. Sim, C. Park, J. Mar. Sci. Tech. 20, 274 (2012)

4. S.H. Song, K.S. Choi, Y.C You, K.H. Kim, H.D. Yun, J. Korea Concr. Inst. 21, 431 (2009)

5. S. Shahidan, H.B. Koh, A.M.S Alansi, Y.L. Loon, MATEC Web Conf. 47, 2 (2016)

6. R. Akash N.J. Kumar, M. Sudhir, Resour. Conserv. Recy. 50, 1 (2007)

7. K. McNeil, T.H.K. Kang, Inter. J. Concr. Struct. Mater. 7, 61 (2013)

8. A. Shayan, A. Xu, ACI Mater. J. 100, 371 (2003)

9. K.K. Sagoe-Crentsil, T. Brown, A.H. Taylor, Cement and Concr. Res. 31, 701 (2001)

10. M.C Limbachiya, T. Leelawat, R.K. Dhir, Mater. and Struct. 33, 574 (2000)

11. M. Tsujino, T. Noguchi, M. Tamura, M. Kanematsu, I. Maruyama, J. Adv. Concr. Tech. 5, 13 (2007)

12. J. Junak, A. Sicakova, Pro. Eng. 180, 1284 (2017)

13. V. Spaeth, A. Djerbi-Tegguer, Inter. J. Sustain. Built E. 2, 143 (2013) 
14. V.P. Kukadia, D.N. Parekh, R.K Gajjar, IJCIET 8, 351 (2017)

15. The National Standardization Agency of Indonesia, SNI 1972: 2008 Cara Uji Slump Beton (2008)

16. The National Standardization Agency of Indonesia, SNI 1974: 2011 Cara Uji Kuat Tekan Beton dengan Benda Uji Silinder (2011)

17. The National Standardization Agency of Indonesia, SNI 03-2491-2002 Metode Pengujian Kuat Tarik Belah Beton (2002)

18. The National Standardization Agency of Indonesia, SNI 03-4169-1996 Metode Pengujian Modulus Etastisitas Statis dan Rasio Poison dengan Kompresor Ekstensometer (1996)

19. The National Standardization Agency of Indonesia, SNI 03-2834-2000 Tata Cara Pembuatan Rencana Campuran Beton Normal (2000) 